\title{
Influence of public governance on the efficiency in the allocation of public resources
}

\author{
Rodolfo Rocha dos Santos ${ }^{1}$ \\ Suliani Rover ${ }^{2}$ \\ 1 Universidade Federal Rural do Rio de Janeiro / Departamento de Ciências Contábeis e Finanças, Seropédica / RJ — Brazil \\ 2 Universidade Federal de Santa Catarina / Programa de Pós-Graduação em Contabilidade, Florianópolis / SC — Brazil
}

This study sought to verify the influence of public governance practices on the efficiency in the application of public resources in education and health in Brazilian municipalities, based on the perspective of the new public governance (NPG). A municipal efficiency index (MEI) to measure the efficiency in the allocation of public resources in education and health in Brazilian municipalities in 2010. Then, using the statistical models of Ordinary Least Squares, bootstrapped Tobit regression, and quantile regression, the influence of variables considered principles of public governance: transparency/accountability, participation, integrity/ethics, legal conformity, equity, and effectiveness. In conclusion, the study shows that public governance practices influence the efficiency in the application of public resources in education and health in Brazilian municipalities.

Keywords: public governance; efficiency; public administration; performance evaluation; public spending.

\section{Influência da governança pública na eficiência da alocação dos recursos públicos}

Este estudo buscou verificar a influência de práticas de governança pública na eficiência da aplicação dos recursos públicos em educação e saúde nos municípios brasileiros, a partir da perspectiva da nova governança pública (new public governance - NPG). Para atingir tal objetivo, construiu-se um índice de eficiência municipal (IEM) com o intuito de medir a eficiência da aplicação dos recursos públicos com educação e saúde dos municípios brasileiros no ano de 2010. Posteriormente, por meio de modelos estatísticos de regressões de Mínimos Quadrados Ordinários, Tobit bootstraping e quantílica, verificou-se a influência de variáveis tidas como princípios de governança pública: transparência/accountability, participação, integridade/ética, conformidade legal, equidade e efetividade. Como conclusão, este artigo mostra que práticas de governança pública influenciam a eficiência da aplicação dos recursos públicos em educação e saúde nos municípios brasileiros.

Palavras-chave: governança pública; gestão pública; eficiência; avaliação de desempenho; gastos públicos.

\section{Influencia de la gobernanza pública en la eficiencia de la asignación de los recursos públicos}

Este estudio buscó verificar la influencia de prácticas de gobernanza pública en la eficiencia de la aplicación de los recursos públicos en educación y salud en los municipios brasileños, desde la perspectiva de la nueva gobernanza pública (NPG). Para alcanzar tal objetivo, se construyó un índice de eficiencia municipal (IEM) con la intención de medir la eficiencia de la aplicación de los recursos públicos en educación y salud en los municipios brasileños en el año 2010. Posteriormente, por medio de modelos estadísticos de regresiones de Mínimos Cuadrados Ordinarios, Tobit bootstraping y cuantílica, se verificó la influencia de variables consideradas como principios de gobernanza pública: transparencia/accountability, participación, integridad/ética, cumplimiento legal, equidad y efectividad. Como conclusión, este artículo muestra que las prácticas de gobernanza pública influencian la eficiencia de la aplicación de los recursos públicos en educación y salud en los municipios brasileños.

Palabras clave: gobernanza pública; eficiencia; educación; salud; gastos públicos. 


\section{INTRODUCTION}

Recent events have demanded the state to reinvent itself to better perform its social functions. According to Matias-Pereira (2010), examples of such events are the global financial and economic crisis, the welfare state crisis in developed countries, the crisis developmentalism in developing countries, the exhaustion of the economic model, the fragility of the political model, and the deficiency of the administration model.

The context of the last thirty years led the state to reaffirm its role of supporting the market, by measuring, stimulating, and promoting interventions and regulations, requiring from government officials and public managers the adoption of innovative actions in the public sector (Matias-Pereira, 2010). The state and society relationship assumes another perspective: the state changes from an approach limited to exercise government, to an approach centered on governance (Kissler \& Heidemann, 2006).

As for the role of governance, Kormendi and Meguire (1985) were the first authors to establish a relationship between public governance practices and the nations' economic growth. The authors introduced a measure of civil liberties in their set of variables and observed a positive correlation with economic growth. Since then, other studies on this issue have emerged (Asatryan \& Witte, 2015; Chang, 2014; A. G. Oliveira \& Pisa, 2015). However, it is possible to observe a more macroeconomic understanding about this phenomenon, which, on the other hand, leads to wonder whether the relationship between public governance and economic growth is also perceived at the microeconomic level.

This study presents a microeconomic preoccupation by focusing on understanding the efficient allocation of resources in the areas of education and health, which are crucial for the population's quality of life and the nation's development. It is worth mentioning that studies on efficiency in the allocation of public resources for socioeconomic development are quite common in the literature.

Peña (2008) explains that efficiency is the optimal combination of resources and methods (inputs) needed in the production process so that it produces maximum products (output). Efficiency is, therefore, the ability to conduct the right activities, to use minimum input to obtain maximum output, and thereby optimize resource utilization. Mello, Angulo-Meza, Gomes, Fernandes, and Biondi (2008) state that efficiency consists of comparing what was produced, given the available resources, with what could have been produced with the same resources.

Among the several methodologies that allow evaluating efficiency, Peña (2008) observes the successful use of the data envelopment analysis (DEA) method in studies on public administration efficiency.

The research problem addressed here arises around the non-adoption of measures of public governance by governmental institutions, which can reduce efficiency in resource application, resulting in fewer benefits to society and less economic growth. Therefore, when ignoring the influence of public governance practices on local public administration (at the municipalities level), there is the risk of reducing the social welfare provided by the state. Thus, the research question that entails the objective of this study is:

- What is the influence of public governance practices on the efficiency in the allocation of public resources in education and health in Brazilian municipalities? 
The research presents an output-oriented DEA model with variable returns to scale (VRS), to measure the efficiency in the allocation of public resources in education and health in Brazilian municipalities for the year 2010, and the municipal efficiency index (MEI), as presented by Costa, Ferreira, Braga, and Abrantes (2015). Subsequently, we applied the ordinary least squares regression (OLS), bootstrapped Tobit, and quantile regression models to verify the influence of public governance variables on the constructed efficiency scales and the MEI - variables based on the principles of public governance according to Pisa (2014).

This article is divided into five sections, including this introduction, which contextualizes the topic of public governance practices. The second section elucidates the public governance movement, its concepts, and principles, and presents the issue of efficiency in the allocation of resources. The third section presents the efficiency scale models constructed from the DEA, the MEI, and the statistical models to verify the influence of public governance practices on the efficiency in the allocation of public resources in education and health in Brazilian municipalities. Section four presents the results obtained, and the fifth section brings the conclusion and suggestions for future research.

\section{THEORETICAL FRAMEWORK}

\subsection{Public governance movement}

While some scholars and practitioners follow neoliberal ideas and advocate for the application of principles of private organizations in public management, with managerialist movements, others believe in the concept of public administration as an instrument of democracy (Dias \& Cario, 2014a; Kickert, 1997; Pedersen \& Johannsen, 2018). In this way, along with the emergence of the new public management (NPM) and other managerialist movements, a public administration movement known as public governance has emerged, which is being debated with a multidisciplinary approach (Dias \& Cario, 2014a; Lynn \& Malinowska, 2018).

Social movements argue that the efficiency and inclusiveness of public sector services can revive the ethos of governance practice to stimulate public interest (Mandeli, 2016). This can be achieved through the promotion of community networks and can encourage multi-agent collaboration. Both arguments can be considered the primary motivation for public sector reform and can be seen as the theoretical foundations of new public governance (NPG) (Considine \& Lewis, 2003).

In the studies comparing public governance with NPM, some authors, such as Hood (1991), prefer to use them as synonyms, to illustrate changes that have promoted managerial reforms and changes in "orthodox" routines of public management. However, most scholars (Dias \& Cario, 2014b; Kickert, 1997; Kissler \& Heidemann, 2006; Mandeli, 2016; Peters \& Pierre, 1998) argue that the concepts represent different things.

Secchi (2009, p. 358), used the prominent definition of public administration, adopted in political sciences: "it is a horizontal model of relationship, between public and private actors in the process of elaboration of public policies."

For Dias and Cario (2014b), public governance is more than a simple tool of public administration; it is a movement of public management reform. The authors define public governance as:

journal of PUblic administration ｜ Rio de Janeiro 53(4):732-752, July - Aug. 2019 
[...] a developmentalist strategy adopted in the relationship between state and society to build the public sphere, involving the target public seeking to meet the interests of this target public. In other words, this is a type of governance that uses democratic processes to design the solutions demanded by twenty-first-century society (Dias \& Cario, 2014b, p. 93).

Kickert (1997) defines public governance as the management of complex networks, consisting of many different actors of national, provincial, and local government, political and social groups, lobby groups, action groups, and interest groups, social institutions, private organizations, and others. The management of such public networks is a form of external government control. Public governance means influencing social processes in a network of public policies of many other actors.

According to Lynn and Malinowska (2018), public governance is an interdisciplinary field of study focused on power relations between government authorities, civil society, and the market, in a context of transformations in the ability of legitimate political communities to govern and act effectively.

Finally, Pedersen and Johannsen (2018) show that NPG emphasizes that more efficient services and better results can be achieved through flexible administrative processes in which trust, the inclusion of citizens, and enhancement of public-private relational contacts operate as a core mechanism of governance.

\subsection{Principles of public governance}

According to the World Bank, some elements are essential for public governance to be effective, such as the rule of law, civil society participation in public affairs, a bureaucracy with professional ethics, policies planned in a predictable, open, and transparent way, and an executive arm that takes responsibility for the actions (World Bank, 2007; Tribunal de Contas da União [TCU], 2014).

The World Bank's principles of good governance are legitimacy, equity, accountability, efficiency, probity, transparency, and accountability (Pisa, 2014).

Pisa (2014) points out that there is a growing concern over transparency, accountability, integrity, and participation when discussing principles of public governance. For Matias-Pereira (2010) there are four principles of public governance: a) ethical relations; b) conformity in all dimensions; c) transparency; and d) accountability. The author argues that the element "proactive participation of all actors involved, leaders, politicians, control bodies and, in particular, organized society," is essential for good governance (Matias-Pereira, 2010, p. 124).

Pisa (2014) uses the following principles of public governance: a) transparency; b) accountability; c) participation; d) integrity/ethics; e) legal conformity; f) equity; and g) effectiveness. The author emphasizes that the principles of transparency, accountability, integrity, and participation are almost unanimous in the literature. Box 1 illustrates the concept of each principle of public governance presented by Pisa (2014). 


\begin{tabular}{|c|c|}
\hline Principles & Concept \\
\hline Transparency & $\begin{array}{l}\text { Regarding the governance practices, "providing citizens with more information on, and access } \\
\text { to, government and its decision-making processes makes a significant contribution to greater } \\
\text { openness within the administration" (Organization for Economic Co-Operation and Development } \\
\text { [OECD], 2001, p. 73). }\end{array}$ \\
\hline Accountability & $\begin{array}{l}\text { Refers to the public manager's obligation to be accountable, of decision and actions, to the society } \\
\text { that granted them this mandate, which necessarily implies in reprimand for misconduct (Pisa, 2014) }\end{array}$ \\
\hline Participation & $\begin{array}{l}\text { The quality, relevance, and effectiveness of policies depend on participation throughout the } \\
\text { processes around a policy, from its elaboration until implementation. Participation promotes } \\
\text { confidence both regarding the outcomes and the institutions which deliver policies (European } \\
\text { Commission, 2001). }\end{array}$ \\
\hline Integrity/ethics & $\begin{array}{l}\text { "It is based upon honesty and objectivity, and high standards of propriety and probity in the } \\
\text { stewardship of public funds and resources, and management of an entity's affairs. It is dependent } \\
\text { on the effectiveness of the control framework and the personal standards and professionalism of } \\
\text { the individuals within the entity. It is reflected both in the entity's decision-making procedures and } \\
\text { in the quality of its financial and performance reporting" (International Federation of Accountants } \\
\text { [IFAC], 2001, p. 12). }\end{array}$ \\
\hline Legal conformity & $\begin{array}{l}\text { It is related to following the public administration's laws and regulations. The public manager must } \\
\text { observe the principle of legality, while acting with efficiency and effectiveness, serving the public } \\
\text { interest (Pisa, 2014). }\end{array}$ \\
\hline Equity & $\begin{array}{l}\text { The concept of equity is strongly related to the concept of justice. It assumes offering unequal } \\
\text { treatment to different subjects to reach equality, acknowledging the inequalities created in the } \\
\text { polis (Aristóteles, 2002). }\end{array}$ \\
\hline Effectivity & $\begin{array}{l}\text { Impacts of products/services, processes, or projects. Effectivity is related to } 3+\text { the satisfaction or } \\
\text { added value (Pisa, 2014). }\end{array}$ \\
\hline
\end{tabular}

Source: Adapted from Pisa (2014).

This study used the principles of public governance by A. G. Oliveira and Pisa (2015). It is worth emphasizing that the authors explore the concept of effectiveness in their 'public governance index.' This research adopted the variables of public governance considered by A. G. Oliveira and Pisa (2015) as indicators in order to build the public governance evaluation index (IGovP). These indicators were applied to each of the principles adopted to verify the efficiency in the application of public resources in education and health in relation to the variables. It is understood that the search for an effective application of the public resources is one of the objectives of the public administration to reach the effectiveness of public policies (I. G. S. Oliveira, 2015). A. G. Oliveira and Pisa (2015, p. 1271) further state that:

[...] in order to develop governance indicators, it is crucial to take into account some criteria of analysis, such as: [...] efficiency, as long as the policies reflect the adequate social return due to the use of scarce resources. 


\subsection{Efficiency in the allocation of public resources}

According to Chan and Karim (2012, p. 8):

Public spending efficiency is defined as the ability of the government to maximize its economic activities given a level of spending, or the ability of the government to minimize its spending given a level of economic activity. Hence, public spending efficiency could be used as an indicator to evaluate the effectiveness of government policy implementation on administration, education, health, income distribution, and economic stability. It is crucial for the government to spend the money collected from taxpayers efficiently, as it is accountable to its citizens. The fundamental question of economics is concerned with the efficient use of scarce resources. In this context, the concept of efficiency provides an evaluation of a country's allocation of resources in promoting economic growth.

The government's performance reflects the performance and outcomes obtained in sectors such as administration, education, health, income distribution, income stability, and economic performance (Baciu \& Botezat, 2014). The indicators in these sectors are commonly used in the literature as benchmarks of government performance (Afonso, Schuknecht, \& Tanzi, 2010).

This research emphasizes the importance of investments in education and health for economic growth and reduction of social discrepancies - both regarding well-being and income - following Guerreiro Ramos' (1989) notion of para-economic development.

The choice of education and health as the focus of the analysis in this research is supported by Araújo-Júnior, Justo, Rocha, and Gomes (2017) who argue that education is the most convenient way to promote the development of a country. The United Nations Educational, Scientific and Cultural Organization (Unesco, 1998) corroborates this notion stating that basic education is a pillar that structures a country's human capital.

According to Lopes, Toyoshima, and Gomes (2009), the poor situation of public health in developing countries is accentuated by the vulnerable socioeconomic conditions experienced by the majority of the population. The authors reinforce that the public health system is of vital importance to reduce the overall problems of the most disadvantaged population, more vulnerable to diseases (Lopes et al., 2009).

Thus, inefficiency in the application of public resources in education and health only exacerbates social inequality and undermines a country's economic growth.

In this sense, Asatryan and Witte (2015) studied the role of direct and participatory democracy in the efficient provision of public goods by the municipalities of the German state of Bavaria. The authors found that more democratic practices are associated with higher government efficiency in the provision of goods and services, suggesting that public governance practices have positive effects on the efficiency of the state.

Chang (2014) looked at the relationship between public governance and the efficiency of China's and Taiwan's electricity generating companies. The author demonstrated that good public governance has contributed to improving the efficiency of the Chinese electric power industry.

In Brazil, J.L.M. Silva and Almeida (2012) used the DEA to create an efficiency scale for the municipalities of the state of Rio Grande do Norte regarding public spending on education and, through the Tobit regression model, verified the impact of several variables, such as the existence of Muncipal Council of Education, on the inefficiency obtained by decision-making units (DMU). The

Journal of Public administration ｜ Rio de Janeiro 53(4):732-752, July - Aug. 2019 
authors observed a negative relationship between the inefficiency of municipalities and the existence of Muncipal Councils of Education, which suggests an increase in the efficiency of the state apparatus based on governance practices.

\section{METHODOLOGY}

\subsection{Data envelopment analysis}

There are numerous methodologies for measuring efficiency. According to Lampe and Hilgers (2015), the most commonly used is data envelopment analysis (DEA). Several studies in the field of public administration have used DEA to measure efficiency, such as J. L.M. Silva and Almeida (2012), Sibiano and Agasisti (2013), Costa et al. (2015), Samut and Cafri (2016).

This study adopted the DEA model with variable returns to scale (DEA-VRS). We opted for an output-oriented DEA, which measures how much production can be expanded without changing inputs, as expressed by the following equation:

$$
\begin{aligned}
& \operatorname{Max} E_{c}=\sum_{j=1}^{S} u r+y_{r o}+u_{*} \\
& \text { S. } a .: \sum_{i=1}^{m} v_{i} x_{i c}=1 \\
& \sum_{j=1}^{S} u_{r} y_{r j}+u_{*}-\sum_{i=1}^{m} v_{i} x_{i o} \leq 0, \forall j \\
& u_{r} \geq 0, v_{i} \geq 0, \forall r, i \\
& u_{*} \in \Re
\end{aligned}
$$

In addition, the BCC-DEA Model (Bankers, Charnes, \& Cooper, 1984) was used, as suggested by Souza and Gasparini (2006), in order to take into consideration the size disparity between decisionmaking units (DMU).

\subsection{Research Universe}

The research universe was the Brazilian municipalities that presented enough data to build efficiency scales in the year 2010. In that year, Brazil had 5,565 municipalities. The sample was formed by excluding the municipalities that did not present information on at least one variable or those that presented a variable with values above three standard deviations in the standardized test (Z-test $)^{1}$, as

\footnotetext{
${ }^{1}$ The standardized test score is expressed in the following equation:

$Z_{i}=\frac{x i-\bar{x}}{S}$

Where:

$\bar{x}$ is the sample mean

$\mathrm{S}$ is the sample standard deviation
} 
in Diniz (2012). After this procedure, the sample counted 3,193 Brazilian municipalities, representing $57.37 \%$ of Brazilian municipalities in 2010.

The year 2010 was chosen because it was the last time the national census was conducted. Faria, Jannuzzi, and Silva (2008) justify that, given the strictness of the public budget, the allocation of public resources in education and health for one year can be generalized for some of the following years.

\subsection{Construction of the efficiency scale and the municipal efficiency index}

Table 2 presents the variables used to measure the Brazilian municipalities' efficiency of the application of public resources in education.

\section{BOX 2 VARIABLES USED AS INPUTS AND OUTPUTS FOR EDUCATION}

\begin{tabular}{|c|c|}
\hline Inputs & Description \\
\hline SpsEdu & $\begin{array}{l}\text { Spending per student on education: municipal spending in education, divided by } \\
\text { the total number of students in primary and secondary education. }\end{array}$ \\
\hline Fiscal value added per capita & Municipal Gross Domestic Product (M-GDP) per capita. \\
\hline Outputs & Description \\
\hline IDEB $5^{\text {th }}$ grade & $\begin{array}{l}\text { Índice de desenvolvimento da educação básica (Index of development of basic } \\
\text { education) (IDEB) of students in the } 5^{\text {th }} \text { year of primary education. }\end{array}$ \\
\hline IDEB $9^{\text {th }}$ grade & IDEB of students in the $9^{\text {th }}$ year of primary education. \\
\hline InRateBelow\% & $\begin{array}{l}\text { Inverse of the rate of } 6 \text { to } 14 \text { year old students in basic education who are } 2 \text { or } \\
\text { more years behind their peers. }\end{array}$ \\
\hline RateAtt6to14\% & Number of children aged 6 to 14 years old attending school. \\
\hline
\end{tabular}

Source: Elaborated by the authors.

The variable SpsEdu considered all the municipality expenditures in education weighted by the total of students of primary and secondary education in each municipality. This variable is used, therefore, to measure the allocation of public resources in education.

The fiscal value added per capita is measured by the municipal gross domestic product (M-GDP) weighted by the total population of the municipality. This variable aims to capture the possible effects of the municipality's wealth on the efficiency in the allocation of public resources. The use of this variable is inspired by the works of A. A. P. Silva, Ferreira, Braga, and Abrantes (2012) and Costa et al. (2015).

As for the outputs, we searched for variables that comprised the three components presented by Araújo, Conde and Luzio (2007): a) educational performance component; b) age-series adequacy component; and c) school attendance component.

The variables presented in Box 3 were selected to build the scale for efficiency in the allocation of public resources in health. 


\begin{tabular}{|c|c|c|}
\hline Inputs & Description & Source \\
\hline SpcHealth\&San & $\begin{array}{l}\text { Per capita spending in health and sanitation: } \\
\text { municipal spending in health and sanitation. }\end{array}$ & $\begin{array}{l}\text { Secretaria do Tesouro Nacional (Brazilian } \\
\text { National Treasury) (STN). }\end{array}$ \\
\hline $\begin{array}{l}\text { Fiscal value added per } \\
\text { capita }\end{array}$ & $\begin{array}{l}\text { Municipal Gross Domestic Product (M-GDP) per } \\
\text { capita. }\end{array}$ & $\begin{array}{l}\text { Instituto Brasileiro de Geografia e Estatística } \\
\text { (Brazilian Institute of Geography and Statistics) } \\
\text { (IBGE). }\end{array}$ \\
\hline Outputs & Description & Source \\
\hline PsPSF\% & $\begin{array}{l}\text { Percentage of the population served by the } \\
\text { Programa Saúde da Familia (Brazilian program of } \\
\text { family healthcare) (PSF). }\end{array}$ & Ministério da Saúde (Brazilian Ministry of Health). \\
\hline InChMorRate\% & Inverse child mortality rate. & IBGE. \\
\hline LiveBirthM7pnv\% & $\begin{array}{l}\text { Percentage of live births to mothers who attended } \\
7 \text { or more prenatal medical visits. }\end{array}$ & $\begin{array}{l}\text { Pesquisa Nacional por Amostra de Domicílios } \\
\text { (National Household Sample Survey) (PNAD). }\end{array}$ \\
\hline ProPerHouswSan\% & $\begin{array}{l}\text { Proportion of private and permanent households } \\
\text { with the adequate sanitation system }\end{array}$ & PNAD. \\
\hline
\end{tabular}

Source: Elaborated by the authors.

The variable SpcHealth\&San includes health and sanitation expenses weighted by the total population of each municipality studied. The costs of sanitation are considered because there is a relationship between the provision of water and sewage services and the reduction of child mortality (K. E. A. Cruz \& Ramos, 2012).

Similarly to the model for allocation of public resources in education, in the case of health, the municipal gross domestic product (M-GDP) per capita is considered a non-discretionary variable.

Regarding the outputs, we used those related to the development and protection of health and treatment and follow-up services. Because there are very different structures among Brazilian municipalities and their health systems, in addition to several actions performed under shared competence among municipalities, states, and federal government, we compared the performance of municipalities in relation to direct outcomes related to basic health care, which is an exclusive responsibility of each municipality (Varela, Martins, \& Fávero, 2012).

The Open Source DEA software was used to generate the scales of efficiency in the allocation of public resources in education and health.

After building the scales, we adapted the Municipal Efficiency Index (MEI) proposed by Costa et al. (2015).

This research only uses the allocation in education and health, according to the following equation:

$$
M E I_{i j}=\theta_{\text {edu }} \times \frac{\text { Sedu }}{\text { Stotal }}+\theta_{\text {health }} \times \frac{\text { Sheealth }}{\text { Stotal }}
$$


Where: MEI represents the municipal efficiency index for the i-th municipality of the sample for year $\mathrm{j}, \theta$ is the relative efficiency score obtained by the DEA in education and health, in which it is multiplied by the ratio between the spending in each analyzed dimension and the municipality's total spending (Costa et al., 2015).

The aim was to construct the MEI in order to analyze, in a single index, the efficiency in the allocation of public resources in education and health.

\subsection{Data analysis procedures}

\subsubsection{Adopted models}

According to Hoff (2007), both the Tobit regression and the ordinary least squares (OLS) models are sufficient for the so-called "second stage DEA". However, Adkins (2014) states that the Tobit regression model is more suitable for the second stage DEA since the abruptness of the efficiency makes the OLS a biased model.

Diniz (2012) argues that the use of the Tobit method does not have consistent grounds. Simar (2003) showed that the Tobit intervals are far from the real $\beta$ values estimated by bootstrapping.

The bootstrapped Tobit is used to obtain greater robustness in non-parametric methods (Diniz, 2012). By obtaining the same limits numerous times, by bootstrapping, the existing correlation of $\beta$ values is eliminated, also excluding the random part of the error that can resort to an inefficiency (Diniz, 2012).

According to Costa et al. (2015), these models of censored analysis do not consider the case in which the variables related to the production system may not influence the units observed in the same way. Thus, Costa et al. (2015) argue that this problem can be overcome by using quantile regression in order to verify the differences in the association between the variables studied in the distribution quantiles.

This study, therefore, applied an OLS model, a bootstrapped Tobit regression, and a quantile regression model.

\subsubsection{Explanatory variables}

In order to verify the influence of public governance practices on the efficiency in the allocation of public resources in education and health, we selected variables that represent indicators associated with the principles of public governance presented above.

Box 4 presents the principles of public governance, the variables used as proxies to measure them, and the source of the data.

\section{BOX 4 PUBLIC GOVERNANCE VARIABLES}

\begin{tabular}{llll} 
Principles & \multicolumn{1}{c}{ Variable } & \multicolumn{1}{c}{ Source } & $\begin{array}{c}\text { Expected } \\
\text { relationship }\end{array}$ \\
\hline $\begin{array}{l}\text { Transparency and } \\
\text { accountability }\end{array}$ & $\begin{array}{l}\text { Índice de responsabilidade fiscal, social e gestão } \\
\text { (Index of managerial, social, and fiscal responsibility) }\end{array}$ & $\begin{array}{l}\text { Confederação Nacional de } \\
\text { Municípios (National Confederation of } \\
\text { (IRFS). }\end{array}$ & Municipalities) (CNM). \\
\hline
\end{tabular}




\begin{tabular}{|c|c|c|c|}
\hline Principles & Variable & Source & $\begin{array}{l}\text { Expected } \\
\text { relationship }\end{array}$ \\
\hline \multirow[t]{4}{*}{ Participation } & $\begin{array}{l}\text { Percentual de eleitores: votos válidos versus } \\
\text { eleitores aptos - percentual no } 1^{0} \text { turno } \\
\text { (Percentage of voters: valid votes vs eligible voters - } \\
\text { percentage in the } 1^{\text {st }} \text { round) (EIV/EIA\%). }\end{array}$ & $\begin{array}{l}\text { Tribunal Superior Eleitoral (Superior } \\
\text { Electoral Court) (TSE). }\end{array}$ & Positive \\
\hline & $\begin{array}{l}\text { Taxa de participação em Conselhos Nacionais e } \\
\text { Municipais (Rate of participation in National and } \\
\text { Municipal Councils)(TxParCM). }\end{array}$ & IBGE. & Positive \\
\hline & $\begin{array}{l}\text { Presença de Conselho Municipal de Educação } \\
\text { (Existence of a Municipal Council of Education) } \\
\text { (PresCME). }\end{array}$ & $\begin{array}{l}\text { Website of the União Nacional dos } \\
\text { Conselhos Municipais de Educação } \\
\text { (National Union of the Municipal } \\
\text { Councils of Education) }\end{array}$ & Positive \\
\hline & $\begin{array}{l}\text { Presença de Conselho Municipal de Saúde } \\
\text { (Existence of a Municipal Council of Health) } \\
\text { (PresCMS). }\end{array}$ & PNAD. & Positive \\
\hline Integrity/ethics & $\begin{array}{l}\text { Direitos humanos: taxa de trabalho infantil (Human } \\
\text { rights: child labor rate) (Trablnf). }\end{array}$ & 2010 Brazilian demographic census & Negative \\
\hline Legal conformity & IRFS Fiscal (IFRSF). & CNM. & Positive \\
\hline \multirow[t]{3}{*}{ Equity } & Índice de Gini (Gini Index) (IndGini). & 2010 Brazilian demographic census & Negative \\
\hline & $\begin{array}{l}\text { Taxa de analfabetismo da população de } 15 \text { anos } \\
\text { ou mais (lliteracy rate - \% of people ages } 15 \text { and } \\
\text { above) (TxAnalf). }\end{array}$ & 2010 Brazilian demographic census & Negative \\
\hline & $\begin{array}{l}\text { Taxa de desemprego: percentual da população } \\
\text { de } 16 \text { anos ou mais, economicamente ativa, } \\
\text { desocupada (Unemployment rate: percentage of } \\
\text { people ages } 16 \text { and above, economically active } \\
\text { population, unoccupied) (TxDes). }\end{array}$ & 2010 Brazilian demographic census & Negative \\
\hline \multirow[t]{2}{*}{ Effectivity } & $\begin{array}{l}\text { Renda média domiciliar per capita percentual } \\
\text { (Average household income per capita - percentage) } \\
\text { (RendMDpc). }\end{array}$ & PNAD. & Positive \\
\hline & $\begin{array}{l}\text { Índice de desenvolvimento humano municipal } \\
\text { (Municipal Human Development Index) (IDHM). }\end{array}$ & $\begin{array}{l}\text { United Nations Development Program } \\
\text { (UNDP) in Brazil. }\end{array}$ & Positive \\
\hline
\end{tabular}

Source: Elaborated by the authors.

Note: The abbreviations designating to the public governance variables derive from the variable's name in Portuguese, the language in which the research was conducted.

Control variables were inserted in the model: densidade democráfica (demographic density) (DenDem); percentual de população urbana (percentage of urban population) (PopUrb); média de anos de estudo dos adultos com mais de 25 anos (average years of study of adults over 25) (MedAE); and percentual de pessoas em domicílios com abastecimento de água e esgotamento sanitário inadequados (percentage of people in households with inadequate water supply and sanitary sewage) (ÁguaEsg).

In the model presented in equation 3, the MEI is a dependent variable and the indicators of public governance are the model's variables of interest: 
IEM $_{i}=\alpha+$ IRFS $_{i} \beta_{1}+$ ElVElA $_{i} \beta_{2}+$ TxCM $_{i} \beta_{3}+$ PresCME $_{i} \beta_{4}+$ PresCMS $_{i} \beta_{5}+$ TranbIf $_{i} \beta_{6}+$ IFRSF $_{i} \beta_{7}+$ IndG $_{i} \beta_{8}+$ TxAnalf $_{i} \beta_{9}+$ TxDes $_{i} \beta_{10}+$ RendMD $_{i} \beta_{11}+$ IDHM $_{i} \beta_{12}+\operatorname{DenDem}_{i} \beta_{13}+$ PopUrb\% ${ }_{i} \beta 1_{4}+$ MedAE $_{i} \beta_{15}+\%$ ÁguaEsg $\beta_{16}+\mathcal{E}$

where $\alpha$ is the constant of the equation, $\beta_{\mathrm{n}}$ is the coefficient that multiplies the variable $n$ of the function and $\varepsilon$ is the error term of the equation.

Stata ${ }^{\circledR}$ software, version 12.0 , was used to estimate the regression models.

\section{RESULTS ANALYSIS AND INTERPRETATION}

Table 1 presents the variance inflation factor (VIF) for all independent variables of the model.

\section{TABLE 1 VARIANCE INFLATION FACTOR OF THE MODEL'S VARIABLES}

\begin{tabular}{|c|c|}
\hline Variable & Variance inflation factor \\
\hline IDHM & 16.36 \\
\hline RendMDpc & 8.56 \\
\hline TxAnalf & 6.48 \\
\hline PopUrb & 2.53 \\
\hline ÁguaEsg & 2.45 \\
\hline IRFS & 2.00 \\
\hline TxParCM & 1.97 \\
\hline IRFSF & 1.78 \\
\hline MedAE & 1.74 \\
\hline TxDes & 1.61 \\
\hline IndGini & 1.43 \\
\hline EIVEIA & 1.38 \\
\hline Trablnf & 1.37 \\
\hline PresCME & 1.19 \\
\hline DenDem & 1.14 \\
\hline PresCMS & 1.06 \\
\hline
\end{tabular}

Source: Elaborated by the authors.

The VIF analysis showed that the variable Municipal Human Development Index (MHDI) had a high inflation factor, which could lead to a multicollinearity problem for the model (Fávero \& Belfiore, 2015). Therefore, MHDI was removed from the regression model. The other variables presented VIF less than 10 and remained in the model.

Table 2 presents the results obtained in the OLS model and the bootstrapped Tobit regression. Due to the results of the Breusch-Pagan test for heteroscedasticity, which presented a chi-squared statistic 
of 38.30, and p-value lower than 0.01 , we decided to use robust standard errors. Thus, the model's residuals are heteroscedastic, and the robust standard errors are assumed to correct this problem.

TABLE 2 MEI - OLS REGRESSION MODEL AND BOOTSTRAPPED TOBIT REGRESSION

\begin{tabular}{|c|c|c|c|c|c|c|c|c|}
\hline \multirow{2}{*}{ Variables } & \multicolumn{4}{|c|}{ OLS } & \multicolumn{4}{|c|}{ Bootstrapped Tobit } \\
\hline & Coefficient & Standard error & P-Value & Sig. & Coefficient & Standard error & P-Value & Sig. \\
\hline EIV/EIA & -0.00255 & 0.00034 & 0.00 & $\star \star \star ~$ & -0.00255 & 0.00033 & 0.00 & 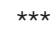 \\
\hline TxParCM & -0.00013 & 0.00016 & 0.42 & & -0.00013 & 0.00015 & 0.41 & \\
\hline PresCME & -0.01371 & 0.00445 & 0.00 & 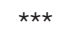 & -0.01371 & 0.00433 & 0.00 & $\star \star \star *$ \\
\hline PresCMS & 0.01123 & 0.01107 & 0.31 & & 0.01123 & 0.01084 & 0.30 & \\
\hline IRFS & 0.21299 & 0.05449 & 0.00 & $\star \star \star$ & 0.21299 & 0.05410 & 0.00 & 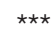 \\
\hline IRFSF & -0.04094 & 0.03837 & 0.29 & & -0.04094 & 0.03750 & 0.28 & \\
\hline Trablnf & -0.00083 & 0.00031 & 0.01 & 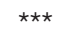 & -0.00083 & 0.00031 & 0.01 & $\star \star * *$ \\
\hline IndGini & -0.16284 & 0.03315 & 0.00 & $\star \star \star$ & -0.16284 & 0.03278 & 0.00 & 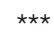 \\
\hline TxAnalf & 0.00043 & 0.00037 & 0.24 & & 0.00043 & 0.00036 & 0.23 & \\
\hline TxDes & -0.00433 & 0.00063 & 0.00 & 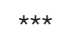 & -0.00433 & 0.00063 & 0.00 & *** \\
\hline RendMDpc & -0.00012 & 0.00002 & 0.00 & 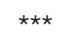 & -0.00012 & 0.00002 & 0.00 & *** \\
\hline DenDem & 0.00000 & 0.00000 & 0.96 & & 0.00000 & 0.00000 & 0.96 & \\
\hline MedAE & 0.02289 & 0.00213 & 0.00 & $\star \star \star \star ~$ & 0.02289 & 0.00209 & 0.00 & $\star \star \star \star ~$ \\
\hline ÁguaEsg & 0.00063 & 0.00011 & 0.00 & 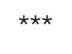 & 0.00063 & 0.00011 & 0.00 & *** \\
\hline PopUrb & -0.01025 & 0.01239 & 0.41 & & -0.01025 & 0.01294 & 0.43 & \\
\hline _cons & 0.33548 & 0.04848 & 0.00 & 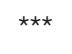 & 0.33548 & 0.04554 & 0.00 & *** \\
\hline $\mathrm{R}^{2}$ & 0.1988 & & & & Pseudo $\mathrm{R}^{2}$ & 0.1275 & & \\
\hline $\mathrm{F}$ & 55.82 & & & & Wald qui² & $1,512.74$ & & \\
\hline Prob $>F$ & 0.0000 & & & & Prob $>$ qui ${ }^{2}$ & 0.0000 & & \\
\hline Observations & 3,193 & & & & Log Likelihood & $3,129.0603$ & & \\
\hline Breusch-Pagan & \multicolumn{3}{|c|}{ qui² 38,30 (valor $p=0,0000$ ) } & & & & & \\
\hline Jaque-Bera & \multicolumn{3}{|c|}{ quil 308,80 (valor $p=0,0000$ ) } & & & & & \\
\hline Note: ${ }^{\star \star \star}$ signific & ee of $1 \%$ & & & & & & & \\
\hline
\end{tabular}

Source: Elaborated by the authors.

As for the principle of public governance 'participation,' only two variables, 'percentage of voters' (ElV/ElA\%) and 'existence of a Municipal Council of Education' (PresCME) were statistically significant, with $99 \%$ confidence level. This result was opposite that expected and diverged from the 
results obtained by Asatryan and Witte (2015) and J. L. Silva and Almeida (2012). Costa et al. (2015) have shown that, in election years, the efficiency in the allocation of public resources decreases as managers spend more in order to meet the demands of parts of the population. This phenomenon may repeat in municipalities where there is a more significant percentage of voters in the population.

As for the principle of 'transparency and accountability', the IRFS had a positive relationship with the MEI. This relationship was statistically significant (1\%) as expected. The results corroborate those presented by C. F. Cruz, Ferreira, Silva, and Macedo (2012). Municipalities that presented greater management transparency and administration indices were those more efficient in the allocation of public resources in education and health.

Regarding the principle of 'integrity/ethics', the variable TrabInf presented a negative relation with the MEI in the allocation of public resources in education and health, converging with the expected result corroborated by Hauner (2008). A child submitted to labor presumably is not enrolled in school, which may have reduced the level of service offered by municipalities that presented higher rates of child labor.

Regarding the principle 'legal conformity', the variable Fiscal IRFS presented a negative relation with the MEI in the allocation of public resource in education and health. However, the effect of this variable was not statistically significant.

Regarding the principle of 'equity', only the variables IndGini and TxDes presented a negative relation with the MEI. Thus, it is possible to say that, at a $1 \%$ significance level, social inequality negatively affects efficiency in the allocation of public resources, and level of unemployment. The result corroborates Hauner (2008) and Lopes and Toyoshima (2008).

Regarding the principle of 'effectiveness', the variable RendMDpc presented a negative relation with the MEI. This result was the opposite of expected and diverged from the results obtained by Lopes and Toyoshima (2008). This result is statistically significant at a 99\% confidence level. Therefore, one can assume that increasing income increases the search for private education and health services.

Finally, among the control variables selected for the regression models, only the variables MedAE and ÁguaEsg were statistically significant, both with a 99\% confidence level. MedAE presented a positive relationship with the MEI, a result that was in line with the expectations, based on the findings by Lopes and Toyoshima (2008) and K. E. A. Cruz and Ramos (2012). It is possible to observe the benefits of the externalities of investments in education, where human capital increases positively, not only in economic growth (Zoghbi, Matos, Rocha, \& Arvate, 2009) but also the efficiency in the allocation of public resources. ÁguaEsg presented a positive relationship with the MEI in the allocation of public resources in education and health, diverging from the results expected.

According to $\mathrm{R}^{2}$ of the OLS regression model, the variables that form the model explain $19.88 \%$ of the MEI variations constructed for this research. There was no normality of the residues for the models. However, according to the central limit theorem and taking into account the fact that we had over 300 observations in the sample, the assumption of residue normality was relaxed (Fávero \& Belfiore, 2015).

The results in Table 3 show the degree of association of the variables of public governance with the MEI in the allocation of public resources in education and health in the different quintiles established. 
TABLE 3 MEI - QUANTILE REGRESSION MODEL

\begin{tabular}{|c|c|c|c|c|c|c|c|c|c|c|}
\hline \multirow{3}{*}{$\begin{array}{l}\text { Variables } \\
\text { EIV/EIA }\end{array}$} & \multicolumn{10}{|c|}{ Coefficients } \\
\hline & \multicolumn{2}{|l|}{ q.10 } & \multicolumn{2}{|l|}{ q.25 } & \multicolumn{2}{|l|}{ q.50 } & \multicolumn{2}{|c|}{ q.75 } & \multicolumn{2}{|c|}{ q.90 } \\
\hline & -0.00168 & $\star \star \star$ & -0.00242 & $\star \star \star *$ & -0.00229 & $\star \star \star *$ & -0.00239 & $\star \star \star$ & -0.00361 & 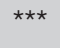 \\
\hline TxParCM & 0.00050 & $\star \star \star$ & 0.00001 & & -0.00016 & & -0.00033 & & -0.00052 & \\
\hline PresCME & -0.01279 & $\star \star$ & -0.01087 & $\star \star$ & -0.01318 & $\star \star$ & -0.01400 & * & -0.01794 & \\
\hline PresCMS & 0.00182 & & 0.02249 & * & 0.00626 & & 0.00361 & & 0.0009 & \\
\hline IRFS & 0.21595 & $\star \star \star \star$ & 0.16770 & $\star \star \star \star ~$ & 0.18682 & 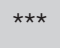 & 0.28113 & $\star \star \star \star ~$ & 0.40037 & $\star \star \star$ \\
\hline IRFSF & -0.08834 & & -0.05739 & & -0.03799 & & 0.03727 & & -0.03717 & \\
\hline Trablnf & 0.00064 & & -0.00016 & & -0.00102 & $* \star \star$ & -0.00129 & 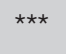 & -0.00177 & ** \\
\hline IndGini & -0.14820 & 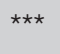 & -0.19376 & 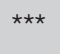 & -0.17018 & 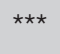 & -0.09800 & * & -0.19237 & $\star \star$ \\
\hline TxAnalf & 0.00323 & & 0.00170 & & 0.00004 & & -0.00103 & * & -0.00148 & * \\
\hline TxDes & -0.00524 & 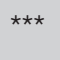 & -0.00455 & 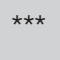 & -0.00438 & 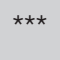 & -0.00437 & 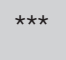 & -0.00386 & $\star \star \star$ \\
\hline RendMDpc & -0.00004 & $\star *$ & -0.00007 & $\star \star \star *$ & -0.00012 & 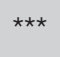 & -0.00018 & 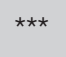 & -0.00015 & $* * *$ \\
\hline DenDem & 0.00000 & * & 0.00000 & & -0.00000 & & 0.00000 & & 0.00000 & \\
\hline MedAE & 0.01937 & 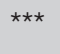 & 0.01837 & 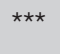 & 0.01992 & 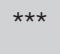 & 0.02569 & 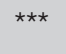 & 0.02606 & $\star \star \star$ \\
\hline ÁguaEsg & 0.00029 & ** & 0.00058 & $\star \star \star *$ & 0.00068 & & 0.00059 & 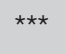 & 0.00090 & $\star \star \star *$ \\
\hline PopUrb & 0.04333 & $\star \star$ & 0.02522 & & -0.00164 & & -0.03100 & & -0.05676 & \\
\hline _cons & 0.06998 & & 0.25941 & 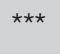 & 0.35912 & $* \star *$ & 0.33705 & *** & 0.54125 & $\star \star \star *$ \\
\hline \multicolumn{11}{|c|}{ Note: ${ }^{*}$ significance of $10 \%$; ${ }^{\star \star}$ significance of $5 \%$; ${ }^{\star \star \star}$ significance of $1 \%$} \\
\hline Pseudo $R^{2} .10$ & 0.1195 & & & & & & & & & \\
\hline Pseudo $R^{2} .25$ & 0.1168 & & & & & & & & & \\
\hline Pseudo $R^{2} .50$ & 0.1151 & & & & & & & & & \\
\hline Pseudo R².75 & 0.1129 & & & & & & & & & \\
\hline Pseudo R².90 & 0.1178 & & & & & & & & & \\
\hline \multicolumn{11}{|c|}{ Wald test: $F=28,57 ;$ Prob $>F=0.0000$} \\
\hline Jaque-Bera: Ch & $455,00(p$ & value & $0.0000)$ & & & & & & & \\
\hline
\end{tabular}

Source: Elaborated by the authors.

In general, the result of quantile regression and other regression models do not differ from each other. However, specific differences may occur when looking at individual quintiles.

Regarding the variables of the 'participation' principle, the ElV/ElA variable presented the same result for all quintiles, repeating the negative relation found in the other regression models, i.e., municipalities with the highest participation in municipal elections presented lower efficiency in the allocation of public resources in education and health. As for the TxParCM, municipalities with 
the lowest MEI (q.10) had a positive relation with this variable, that is, the number of municipal councils positively affects, up to a certain level, the efficiency in the allocation of public resources. This statement can be made due to the $1 \%$ significance level. The result for this variable is what was expected and corroborates the results of J. L. Silva and Almeida (2012) and Costa et al. (2015). It was observed, however, only in the lowest quintile of the sample.

PresCME has negatively affected the efficiency in the allocation of public resources in education and health. All models demonstrated this negative relation, except for the quintile 90 of the quantile regression, where this relationship was not statistically significant. Costa et al. (2015) also demonstrated a negative relationship between the MEI and the presence of municipal councils of education. The PresCMS was only statistically significant with the municipalities in the quintile 25 . This relationship was positive, with a significance level of $10 \%$ and converged with the expectations.

In the same way, as in the other models, the variable IRFSF did not show a statistically significant relationship with any of the quintiles of the quantile regression.

The variable TrabInf showed a statistically significant negative relation only in the highest quintiles (q.50 and q.75 at 1\% significance and q.90 at 5\% significance). The result was as expected and corroborates the results of Hauner (2008).

The IndGini repeated the results found in previous models. This result reinforces that social inequality undermines the efficiency in the allocation of public resources. Regarding TxAnalf, in the OLS models and the bootstrapped Tobit regression, there was no statistically significant relation. Notwithstanding, in the quantile regression model, this negative relation was statistically significant in quintiles 75 and 90 . TxDes repeats the result observed in the previous models.

RendMDpc, a variable used to measure the public governance principle of 'effectiveness', also repeated the results for all regression models. It is possible to assume that an increase in income leads to an increased search for private health and education services, which results in a decrease in the demand for public services. In this research, the decrease in demand directly affects the efficiency in the allocation of public resources in education and health, since the rates of school attendance and the number of people covered by the public health programs make up the DEA models constructed for this research.

DenDem presented a statistically significant positive relation only to municipalities at quintile 10 . At the significance level of $10 \%$, the population density positively influences the MEI in the allocation of public resources in education and health to a certain level of efficiency. This may be due to higher population density and higher demand for education and health care without the need for greater allocation of resources (J. L. Silva \& Almeida, 2012). In the research by J. L. Silva and Almeida (2012), Varela et al. (2012) and Costa et al. (2015), this relationship is the reverse. The result found here is aligned to those obtained by Lopes and Toyoshima (2008).

MedAE presented a positive relationship with the MEI for all the quintiles, at $1 \%$ level of significance. This result corroborates those obtained previously. In the same way, the variable ÁguaEsg repeated the results found by previous models.

Finally, the variable percentage of the urban population presented a positive relation only in quintile 10 , at a 5\% significance level. That is, municipalities with lower MEI improved efficiency according to the level of urbanization. Costa et al. (2015) also found this relation for municipalities with less MEI. 
According to the Wald test, it is possible to say, at the significance level of $1 \%$, that the slope coefficients of each quantile are different for all explanatory variables. Thus, the quantile regression is adequate to represent the relationship between the explanatory variables and the MEI. The JaqueBera test presented a chi-square statistic of 455 with a $p$-value less than 0.01 . Thus, the null hypothesis of the normality of the residues cannot be accepted. However, taking into account the central limit theorem and considering that the sample allowed more than 300 observations for each quantile, the assumption of the normal distribution of residues was relaxed (Favero \& Belfiore, 2015).

\section{CONCLUSION}

This study aimed to verify the influence of public governance practices on the efficiency in the allocation of public resources in education and health in Brazilian municipalities. Two models of data envelopment analysis (DEA) were used to measure the efficiency in the allocation of public resources and the construction of the municipal efficiency index (MEI). Subsequently, the influence of public governance practices on the MEI constructed was verified.

The IRFS variable, selected to measure the principle of 'transparency and accountability', showed a statistically significant positive relationship with all the regression models used. The result was expected for this variable and corroborated C. F. Cruz et al. (2012). Thus, transparency and accountability, as well as better administration indices, positively influence the efficiency in the allocation of public resources in education and health.

The ElV/ElA variable presented a statistically significant negative relationship in all the regression models. This result was the opposite of the expected for this relationship and diverged from the results obtained by Asatryan and Witte (2015). However, Costa et al. (2015) show that the efficiency in the allocation of public resources tends to decrease in election years when managers make public choices that benefit specific populations. Such a phenomenon may be observed in municipalities that tend to have greater participation of the population in the municipal elections.

The expectation for TxParCM was a positive relationship with the efficiency in the allocation of public resource in education and health. This relationship was only proven for the municipalities with lower MEI in the quantile regression. In this sense, the PresCME negatively influences the MEI. PresCMS only positively influenced the MEI in municipalities in quintile 25 . Thus, the results presented by the variables used to measure the principle of 'participation' were not in line with expectations and diverged from the results obtained by J. L. Silva and Almeida (2012), Asatryan and Witte (2015), and Costa et al. (2015).

The variable TxTrabInf presented a negative relation in all the regression models. The result presented is in line with expectations and corroborates the results of Hauner (2008). Thus, it is possible to affirm that municipalities that work to mitigate child labor are more efficient in the allocation of public resources in education and health. Considering the result described, it can be affirmed that public governance positively influences the efficiency in the allocation of public resources in education and health.

The variables IndGini and TxDes used to measure the principle 'equity', showed a negative influence on the MEI for all the regression models used. This relationship was statistically significant, and its result is in line with expectations. TxAnalf, however, only presented a statistically significant relation 
in quintiles 75 and 90 of the quantile regression, confirming what was expected. The search for equity has shown to influence the efficiency in the allocation of public resources in education and health.

Finally, regarding the principle of public governance 'effectiveness', the variable RendMDpc presented a negative relation with the MEI. This result differs from that expected and the literature. The result may be associated with the search for private education services when there is an increase in income, which can directly affect the attendance rate.

Given the results, this research reached its objective, since it demonstrates the influence of public governance practices on the efficiency in the allocation of public resources in education and health. As a contribution to the literature, it demonstrates the relationship of each principle of public governance with the efficiency in the allocation of public resources in education and health and can help in future decision making. It is worth noting, according to the concepts of public governance outlined in section 2 of this article, the importance of the inclusion of civil society and several actors, as active agents, in networks in the processes of public management (Dias \& Cario, 2014b; Kickert, 1997; Lynn \& Malinowska, 2018, Pedersen \& Johannsen, 2018). This article showed that the effect of the principle 'participation' presented an inverse result as expected according to the literature. Costa et al. (2015) argue that, in election years, the efficiency in the allocation of public resources reduces, as discussed before in this article. When the presence of municipal councils negatively influenced or did not affect the efficiency in the allocation of public resources, the question arises whether there is active attendance and participation of civil society in such councils in the sample studied and how is this participation happening.

As for recommendations for future research, it is essential to highlight that the theme of public governance and its relationship with the performance of the state apparatus is little explored academically in Brazil. Thus, this study reveals several possibilities for future research. For example, it is crucial to understand the Brazilian electoral system in relation with the performance in the allocation of public resources and public choices, since the variable used to measure participation in municipal elections has negatively influenced the efficiency in the allocation of public resources in education and health. Also, it is crucial to explore how civil society is participating in decision-making processes within municipal councils.

We expect that this research will stimulate public managers to seek continuous actions that increase the efficiency in the allocation of resources in order to contribute to socio-economic development. It is also vital to emphasize the importance of public governance to promote the efficiency within the state apparatus and its relevance in the growth of the state, in the sense of reducing the waste of public resources and improving the quality of life and well-being of society as a whole.

Finally, the results of this research should be interpreted with caution as to its generalization, since they are limited to the sample investigated and may be sensitive to the methodological decisions made throughout this study. 


\section{REFERENCES}

Adkins, L. C. (2014). Using gretl for principles of econometrics. Stillwater, OK: Oklahoma State University.

Afonso, A., Schuknecht, L., \& Tanzi, V. (2010). Public sector efficiency: evidence for new EU member states and emerging markets. Applied Economics, 42(17), 2147-2164.

Araújo, C. H., Conde, F. N., \& Luzio, N. (2007). Índice de qualidade da educação fundamental (IQE): proposta para discussão. Revista Brasileira de Estudos Pedagógicos, 85(209), 10-11.

Araújo-Júnior, J. N., Justo, W. R., Rocha, R. M., \& Gomes, S. M. F. P. O. (2017). Eficiência técnica das escolas públicas dos estados do Nordeste: uma abordagem em dois estágios. Revista Econômica do Nordeste, 47(3), 61-73.

Aristóteles. (2002). Ética a Nicômaco (5a ed.). São Paulo, SP: Martin Claret.

Asatryan, Z., \& Witte, K. (2015). Direct democracy and local government efficiency. European Journal of Political Economy, 39, 58-66.

Baciu, L., \& Botezat, A. (2014). A comparative analysis of the public spending efficiency of the new EU member states: a DEA approach. Emerging Markets Finance and Trade, 50(sup4), 31-46.

Banker, R. D., Charnes, A., \& Cooper, W. W. (1984). Some models for estimating technical and scale inefficiencies in data envelopment analysis. Management Science, 30(9), 1078-1092.

Chan, S.-G., \& Karim, M. Z. A. (2012). Public spending efficiency and political and economic factors: evidence from selected East Asian countries. Economic Annals, 57(193), 7-23.

Chang, M.-C. (2014). Efficiency and governance of power corporations: a China and Taiwan analysis. Polish Journal of Environmental Studies, 23(5), 1515-1525.

Considine, M., \& Lewis, J. M. (2003). Bureaucracy, network, or enterprise? Comparing models of governance in Australia, Britain, the Netherlands, and New Zealand. Public Administration Review, 63(2), 131-140.

Costa, C. C. M., Ferreira, M. A. M., Braga, M. J., \& Abrantes, L. A. (2015). Fatores associados à eficiência na alocação de recursos públicos à luz do modelo de regressão quantílica. Revista de Administração Pública, 49(5), 1319-1347.

Cruz, C. F., Ferreira, A. C. S., Silva, L. M., \& Macedo, M. A. S. (2012). Transparência da gestão pública municipal: um estudo a partir dos portais eletrônicos dos maiores municípios brasileiros. Revista de Administração Pública, 46(1), 153-76.

Cruz, K. E. A., \& Ramos, F. S. (2012). Eficiência na gestão do saneamento básico e seus impactos sobre a promoção da saúde: uma aplicação da análise envoltória de dados - DEA. In Anais do 17o Encontro Regional de Economia, Fortaleza, CE.

Dias, T., \& Cario, S. A. F. (2014a). Sociedade, desenvolvimento e o papel estratégico do Estado: uma reflexão sobre o surgimento da governança pública. Ensaios FEE, 35(2), 337-362.

Dias, T., \& Cario, S. A. F. (2014b). Governança pública: ensaiando uma concepção. Contabilidade, Gestão e Governança, 17(3), 89-108.

Diniz, J. A. (2012). Eficiência das transferências intergovernamentais para a educação fundamental de municípios brasileiros (Doctoral thesis). Universidade de São Paulo, São Paulo, SP.

European Comission (2001). European governance - a white paper. Retrieved from http://europa.eu/ rapid/press-release_DOC-01-10_en.htm.

Faria, F. P., Jannuzzi, P. M., \& Silva, S. J. (2008). Eficiência dos gastos municipais em saúde e educação: uma investigação através da análise envoltória no Estado do Rio de Janeiro. Revista de Administração Pública, 42(1), 155-177.

Fávero, L. P., \& Belfiore, P, F. (2015). Análise de dados: técnicas multivariadas exploratórias com SPSS ${ }^{\circ} e$ Stata: Rio de Janeiro, RJ: Elsevier.

Guerreiro Ramos, A. (1989). A nova ciência das organizações. Rio de Janeiro, RJ: Ed. FGV.

Hauner, D. (2008). Explaining differences in public sector efficiency: evidence from Russia’s regions. World Development, 36(10), 1745-1765.

Hoff, A. (2007). Second stage DEA: comparison of approaches for modelling the DEA score. European Journal of Operational Research, 181(1), 425-435. 
Hood, C. (1991). A public management for all seasons? Public Administration, 69(1), 3-19.

International Federation of Accountants. (2001). Study 13: governance in the public sector: a governing body perspective. New York, NY: Author.

Kickert, W. J. M. (1997). Public governance in the Netherlands: an alternative to Anglo-American 'managerialism'. Public Administration, 75(4), 731752.

Kissler, L., \& Heidemann, F. G. (2006). Governança pública: novo modelo regulatório para as relações entre Estado, mercado e sociedade? Revista de Administração Pública, 40(3), 479-499.

Kormendi, R. C., \& Meguire, P. G. (1985). Macroeconomic determinants of growth: crosscountry evidence. Journal of Monetary Economics, 16(2), 141-163.

Lampe, H. W., \& Hilgers, D. (2015). Trajectories of efficiency measurement: a bibliometric analysis of DEA and SFA. European Journal of Operational Research, 240(1), 1-21.

Lopes, L. S., \& Toyoshima, S. H. (2008). Eficiência técnica municipal na gestão dos gastos com saúde e educação em Minas Gerais: seus impactos e determinantes. In Anais do 130 Seminário sobre a Economia Mineira. Diamantina, MG.

Lopes, L. S., Toyoshima, S. H., \& Gomes, A. P. (2009). Determinantes sociais da saúde em Minas Gerais: uma abordagem empírica. In Anais do 7o Encontro Nacional da Associação Brasileira de Estudos Regionais e Urbanos, São Paulo, SP.

Lynn, L. E., Jr., \& Malinowska, A. (2018). How are patterns of public governance changing in the US and the EU? It's complicated. Journal of Comparative Policy Analysis: Research and Practice, 20(1), 36-55.

Mandeli, K. N. (2016). New public governance in Saudi cities: an empirical assessment of the quality of the municipal system in Jeddah. Habitat International, 51, 114-123.

Matias-Pereira, J. (2010). A governança corporativa aplicada no setor público brasileiro. Administração Pública e Gestão Social, 2(1), 109-134.

Mello, J. C. C. B. S., Angulo-Meza, L., Gomes, E. G., Fernandes, A. J. S., \& Biondi, L., Neto. (2008). Estudo não paramétrico da relação entre consumo de energia, renda e temperatura. IEEE Latin America Transactions, 6(2), 153-161.

Oliveira, I. G. S. (2015). Análise de correspondência aplicada a proposições sobre a eficiência e eficácia do processo de compras públicas a partir da percepção de diferentes atores envolvidos. In Anales del 90 Congreso Iberoamericano de Contabilidade de Gestión, Florianópolis, SC.

Oliveira, A. G., \& Pisa, B. J. (2015). IGovP: índice de avaliação da governança pública - instrumento de planejamento do Estado e de controle social pelo cidadão. Revista de Administração Pública, 49(5), 1263-1290.

Organização das Nações Unidas para a Educação, a Ciência e a Cultura. (1998). Declaração Mundial sobre Educação para Todos. Retrieved from http://unesdoc. unesco.org/images/0008/000862/086291por.pdf

Organisation for Economic Co-Operation and Development. (2001). Citizens as partners: information, consultation and public participation in policy-making. Paris, France: Author.

Pedersen, K. H., \& Johannsen, L. (2018). New public governance in the Baltic States: flexible administration and rule bending. Public Performance \&Management Review, 41(3), 648-667.

Peña, C. R. (2008). Um modelo de avaliação da eficiência da administração pública através do método análise envoltória de dados (DEA). Revista de Administração Contemporânea, 12(1), 83-106.

Peters, B. G., \& Pierre, J. (1998). Governance without government? Rethinking public administration. Journal of Public Administration Research and Theory, 8(2), 223-243.

Pisa, B. J.(2014). Uma proposta para o desenvolvimento do índice de avaliação da governança pública (IGovP): instrumento de planejamento e desenvolvimento do Estado (Masters dissertation). Universidade Tecnológica Federal do Paraná, Curitiba, PR.

Secchi, L. (2009). Modelos organizacionais e reformas da administração pública. Revista de Administração Pública, 43(2), 347-369.

Samut, P. K., \& Cafrı, R. (2016). Analysis of the efficiency determinants of health systems in OECD countries by DEA and panel tobit. Social Indicators Research, 129(1), 113-132. 
Sibiano, P., \& Agasisti, T. (2013). Efficiency and heterogeneity of public spending in education among Italian regions. Journal of Public Affairs, 13(1), 12-22.

Silva, A. A. P., Ferreira, M. A. M., Braga, M. J., \& Abrantes, L. A. (2012). Eficiência na alocação de recursos públicos destinados à educação, saúde e habitação em municípios mineiros. Contabilidade, Gestão e Governança, 15(1), 96-114.

Silva, J. L. M., \& Almeida, J. C. L. (2012). Eficiência no gasto público com educação: uma análise dos municípios do Rio Grande do Norte. Planejamento e Políticas Públicas, n. 39, 219-242.

Simar, L. (2003). Detecting outliers in frontier models: a simple approach. Journal of Productivity Analysis, 20(3), 391-424.

Souza, C. V. N., Júnior, \& Gasparini, C. E. (2006). Análise da equidade e da eficiência dos estados no contexto do federalismo fiscal brasileiro. Estudos Econômicos, 36(4), 803-832.
Tribunal de Contas da União. (2014). Governança pública: referencial básico de governança aplicável a órgãos e entidades da administração pública e ações indutoras de melhoria. Brasília, DF: Secretaria de Planejamento, Governança e Gestão.

Varela, P. S., Martins, G. A., \& Fávero, L. P. L. (2012). Desempenho dos municípios paulistas: uma avaliação de eficiência da atenção básica à saúde. Revista de Administração (São Paulo), 47(4), 624-637.

World Bank. (2007). Governance and management. In Independent Evaluation Group, Sourcebook for evaluating global and regional partnership programs: indicative principles and standards (pp. 71-82). Washington, DC: Author.

Zoghbi, A. C. P., Matos, E. H. C., Rocha, F. F., \& Arvate, P. R. (2009). Mensurando o desempenho e a eficiência dos gastos estaduais em educação fundamental e média. Estudos Econômicos, 39(4), 785-809.

\section{Rodolfo Rocha dos Santos}

https://orcid.org/0000-0002-1511-6546

Master's Degree in accounting from the Graduate Program in Accounting of the Federal University of Santa Catarina (PPGC/UFSC); Assistant Professor at the Department of Accounting and Finance of the Federal Rural University of Rio de Janeiro (DCCF/UFRRJ).E-mail: rodolforsantos@ufrrj.br

\section{Suliani Rover}

https://orcid.org/0000-0001-8612-2938

$\mathrm{PhD}$ in controllership and accounting from the Faculty of Economics, Administration, and Accounting of the University of São Paulo (FEA USP); Adjunct Professor at PPGC/UFSC. E-mail: sulianirover@gmail.com 